\title{
Role of Webinars in Medical Educations during Pandemic of COVID 19.
}

Pankaj Raj Nepal

Department of Neurosurgery, B and C Medical College Teaching Hopsital and Research Center, Birtamode, Jhapa, Nepal

\section{Correspondence:}

Dr. Pankaj Raj Nepal

Editor in Chief: Eastern Green Neurosurgery

Deputy Medical Director, Head of Department, Department of Neurosurgery

B \& C Medical College and Teaching Hospital \& Research Center, Birtamode, Jhapa, Nepal.

Email: pankajrajnepal@ gmail.com

Phone no:+977- 9801098106

$\mathrm{A}$

$\mathrm{t}$ the time when I was writing this editorial there were more than six

millions confirmed cases of COVID 19,

more than 370 thousands deaths throughout the world, and 215 countries were affected by coronavirus. ${ }^{1}$ In Nepal alone, there were more than 1400 confirmed cases with 6 deaths due to COVID $19 .^{2}$ Most of the countries in the world are living the life of lockdown and social distancing. So, this data clearly shows panicky situations of the people who are living during this pandemic. ${ }^{3-5}$ At this time most of education hubs like schools, and universities have been shut down since 4-5 months throughout the world. Similarly, conferences and CMEs are also been postponed in most part of the world.

Despite of this deadly situation, the hunger of continuing medical education can be seen in the online platform. The education of different aspects of COVID 19 like microbiological aspects, immunological aspects, pathological aspects, clinical presentation, various modalities of treatment, preventive aspects seems to be common topics of online webinars. ${ }^{6,7}$ Till May 31, 2020 there were more than 148 thousands published 1

Date submitted: $31 / 05 / 2020$

Date accepted: 01/06/2020 scholar articles on COVID 19 in English language throughout the world.

Webinars in medical education has been used since long period of time and most of them used to be performed in smaller groups in places where they could offer high-speed internet connectivity and usually lead by senior doctors. As there is lack of physical presence and need of technical knowledge, these webinars were not very wide spread. Recently due to effect of pandemic there has been a phenomenal shift of concepts on webinars and had increased by more than $300 \%$ in 2020 compared to 2019 A.D.6 Various societies, pharmaceutical companies and other educational institutes are widely using these webinars recently with huge participations. Easy availability of applications in mobile devices, a secure connection platform, wide-spread $4 \mathrm{G}$ connectivity in most part of the world and wide spread use of social media to effectively communicate to the targeted group has made this more fascinating. ${ }^{8}$

Physical conferences has already proven definite role in development of medical education because it has been effectively providing many topics and presentations in a go. It has also provided a direct 
communication during the period of Conferences. ${ }^{9}$ Most of the time these conferences are preceded by hands-on workshop by the experts to enhance the skill in various subject. On the other hand these conferences are quite expensive and need of travel to the conference area has not been very useful to the doctors practicing in rural area.

As the online webinars are increasing throughout the world, it is expected to develop more rapidly in terms of its connectivity and user friendliness. As the effect of COVID 19 doesn't seem to fade away very quickly, it seems that we have to acquaintance with this up growing webinars for continuing our medical educations. Although, most of the communication aspects seems to get addressed more effectively in webinars over time; however, it seems to take much more advancement and development to provide hands on training especially in the field of surgery via this platform. Various developed countries have used virtual reality to fulfill this limitations but it seems to be a very remote possibility in underdeveloped and developing countries. ${ }^{10-12}$

In Nepal, Nepalese society of neurosurgeons (NESON) seems to geared up with live webinars to bring neurosurgeons of Nepal in one learning platform. Till now it has already conducted few webinars and feedback seems to be quite wonderful.

\section{Reference:}

1. Coronavirus Update (Live): 6,160,805 Cases and 371,008 Deaths from COVID-19 Virus Pandemic Worldometer [Internet]. Worldometers.info. 2020 [cited 31 May 2020]. Available from: https://www.worldometers.info/coronavirus/
2. Corona Info- Ministry of Health and Population [Internet]. Covid19.mohp.gov.np. 2020 [cited 31 May 2020]. Available from: https://covid19.mohp.gov.np/\#/

3. Lau H, Khosrawipour V, Kocbach P, Mikolajczyk A, Schubert J, Bania J, Khosrawipour T. The positive impact of lockdown in Wuhan on containing the COVID-19 outbreak in China. Journal of travel medicine. 2020 Apr;27(3):taaa037.

4. Di Domenico L, Pullano G, Sabbatini CE, Boëlle PY, Colizza V. Expected impact of lockdown in Îlede-France and possible exit strategies. medRxiv. 2020 Jan 1.

5. Cohen J, Kupferschmidt K. Countries test tactics in 'war'against COVID-19.

6. Goh PS, Sandars J. A vision of the use of technology in medical education after the COVID-19 pandemic. MedEdPublish. 2020 Mar 26;9.

7. GNLC Webinars: UNESCO learning cities' response to COVID-19 | UIL [Internet]. Uil.unesco.org. 2020 [cited 31 May 2020]. Available from: https://uil.unesco.org/event/gnlc-webinars-unescolearning-cities-response-covid-19

8. Ahrens A, Zaščerinska $\mathrm{J}$, Melnikova $\mathrm{J}$, Ramar $\mathrm{H}$, Clipa O, Andreeva N. Use of Webinars in Higher Education: A Comparative Study of Educators' Experience. In3rd Annual International ScientificPractical Application Conference Trends in Science and Higher Education Studies Under Conditions of Globalization. Panevėžys College, Panevėžys, Lithuania 2015 Oct (pp. 22-23).

9. Fisher J. A Kudos Deficit? Observations On Differing Library Workplace Attitudes Towards Conferences and Webinars. Collaborate: Libraries in Learning Innovation. 2017 Oct 19(2).

10. Dascal J, Reid M, IsHak WW, Spiegel B, Recacho J, Rosen B, Danovitch I. Virtual reality and medical inpatients: a systematic review of randomized, controlled trials. Innovations in clinical neuroscience. 2017 Jan;14(1-2):14.

11. Kühnapfel UG, Kuhn C, Hubner M, Krumm HG, Maass H, Neisius B. The Karlsruhe endoscopic surgery trainer as an example for virtual reality in medical education. Minimally Invasive Therapy \& Allied Technologies. 1997 Jan 1;6(2):122-5.

12. de Faria JW, Teixeira MJ, Júnior LD, Otoch JP, Figueiredo EG. Virtual and stereoscopic anatomy: when virtual reality meets medical education. Journal of neurosurgery. 2016 Nov 1;125(5):110511. 